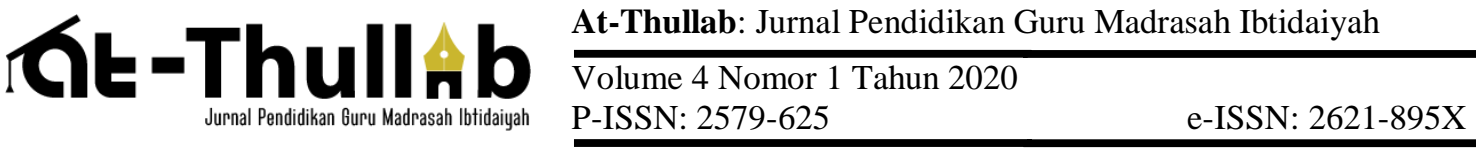

\section{PERSPREKTIF ASESMEN AUTENTIK SEBAGAI ALAT EVALUASI DALAM MERDEKA BELAJAR}

\author{
Wiku Aji Sugiri ${ }^{1}$, Sigit Priatmoko ${ }^{2}$ \\ ${ }^{1,2}$ Universitas Islam Negeri Maulana Malik Ibrahim Malang \\ e-mail: ${ }^{1}$ wikusugiri@uin-malang.ac.id,${ }^{2}$ sigitpriatmoko@uin-malang.ac.id
}

\begin{abstract}
The renewal of the curriculum is an important part of developing the education system in Indonesia. In this renewal, the evaluation section is one important part that must be studied in depth. The research aims to provide an authentic assessment perspective on the renewal that has just taken place, namely Merdeka Belajar. This study uses a descriptive qualitative approach, where researchers are the key to the exposure of data that has been obtained from the field. The study was conducted at SDN Model Banyuwangi with the subject of several teachers, ranging from elementary to high class. The data obtained that is, teachers at the school are able to carry out authentic assessments well. Although in the middle of the implementation there are small obstacles that arise. The authentic assessment provides a detailed assessment of students in the affective, cognitive, and psychomotor aspects. Overall, it can be agreed that the authentic assessments that have been implemented in the 2013 curriculum deserve to be integrated as an evaluation tool in the Merdeka Belajar that was just launched by the Ministry of Education and Culture.
\end{abstract}

Keywords: Authentic Assessments, Merdeka Belajar

\section{A. Pendahuluan}

Pengembangan Pendidikan di Indonesia tidak pernah lepas dari pembaharuan kurikulumnya. Dalam tiap periode tertentu kurikulum selalu mengalami proses evaluasi. Bahkan tak sedikit yang beranggapan bahwa kurikulum itu berganti seiring pergantian pemangku kebijakan.

Sebagai negara yang terus berinovasi dalam pengembangan kurikulum, Indonesia setidaknya telah mengalami lebih dari sepuluh kali perubahan sejak awal kemerdekaan. Mulai dari Rentjana Pembelajaran 1947 hingga yang baru saja hangat diperbincangkan, yakni "Merdeka Belajar." Merdeka Belajar yang dicanangkan oleh Kementerian Pendidikan dan Kebudayaan di bawah komando Nadiem Makarim menambahkan fakta bahwa dalam kurun waktu kurang dari 10 tahun saja Indonesia telah melakukan pembaharuan kurikulum sebanyak 3 kali. Hal tersebut tak lain yaitu untuk menjawab kebutuhan Indonesia yang berubah sesuai kemajuan zaman, baik secara intern maupun ekstern. Dengan demikian, Indonesia diharapkan dapat mempersiapkan perserta didik yang memiliki daya saing di masa yang akan datang. (Khasanah, 2015) 
Merdeka belajar bertujuan untuk membuat pembelajaran lebih bermakna lagi. Adapun secara umum program ini bukan untuk menggantikan program yang telah berjalan, tujuan utamanya adalah memperbaiki sistem yang sudah ada. Merdeka belajar yang digagas Kemendikbud menawarkan proses pembelajaran yang lebih sederhana.

Adit memaparkan bahwa penyederhanaan pelaksanaan pembelajaran tersebut seperti: (1) RPP (rancangan pelaksanaan pembelajaran) yang dibuat oleh guru tidak perlu terlalu banyak dan rumit seperti sebelumnya, (2) sistem zonasi dalam penerimaan peserta didik baru yang telah berjalan sejak beberapa tahun lalu tetap dilaksanakan namun lebih luwes dalam pengimplemenmtasiannya, (3) mulai tahun 2021 ujian nasional yang selama ini menjadi beban bagi pelaku pembelajaran diganti dengan asesmen kompetensi minimum dan survei karakter, dan (4) ujian sekolah berstandar nasional (USBN) dialihkan menjadi asesmen berkelanjutan seperti portofolio (tugas kelompok, karya tulis, praktikum, dan sebagainya) (Adit, 2019).

Jika sebelumnya telah dijelaskan bahwa penilaian dalam merdeka belajar ini diarahkan pada asesmen berkelanjutan, maka dapat disepakati bahwa asesmen autentik yang pernah diimplementasikan pada kurikulum 2013 masih relevan untuk diintegrasikan dengan program tersebut. Asesmen autentik memberikan cara penilaian yang cukup luas terhadap perkembangan siswa. Tidak hanya aspek kognitif yang menjadi acuan utama penialaian, melainkan juga aspek afektif dan psikomotor.

Implementasi Kurikulum 2013 yang sarat dengan karakter dan kompetensi, disertai dengan penilaian secara utuh, terus menerus, dan berkesinambungan, agar dapat mengungkap berbagai aspek yang diperlukan dalam mengambil suatu keputusan (Mulyasa, 2015). Penilaian tersebut bertujuan untuk menjamin bahwa proses kinerja yang dicapai telah sesuai dengan rencana dan tujuan.

Salah satu pihak yang memiliki peran penting dalam proses penilaian ialah pendidik. Dalam Peraturan Menteri Pendidikan No. 104 Tahun 2014 Pasal 1 Tentang Hasil Belajar dijelaskan bahwa penilaian hasil belajar oleh pendidik adalah proses pengumpulan informasi/bukti tentang capaian pembelajaran peserta didik dalam kompetensi sikap spiritual dan sikap sosial, kompetensi pengetahuan, dan kompetensi keterampilan yang dilakukan secara terencana dan sistematis, selama dan setelah proses pembelajaran. Selanjutnya juga dijelaskan bahwa penilaian hasil belajar dilakukan dalam bentuk autentik dan non-autentik.

Permendikbud No. 104 Tahun 2014 memaparkan bahwa penilaian autentik adalah bentuk penilaian yang menghendaki peserta didik menampilkan sikap, menggunakan pengetahuan dan keterampilan yang diperoleh dari pembelajaran dalam melakukan tugas pada situasi yang sesungguhnya.

Implementasi penilaian autentik sebenarnya telah diberi ruang sejak kurikulum tingkat satuan pendidikan (KTSP), namun hal tersebut belum terlaksana secara optimal. 
Kusmijati menjelaskan bahwa belum semua guru paham terhadap pelaksanaan penilaian autentik (Kusmijati, 2014). Hal tersebut dikarenakan belum meratanya pembagian buku panduan guru terhadap sistem pelaksanaan penilaian autentik. Guru hanya sebatas mengetahui pengetian dasar atas penilaian autentik, tapi belum mengetahui cara menerapkannya.

Tujuan penelitian ini adalah untuk mendeskripsikan pelaksanaan penilaian kinerja, pelaksanaan penilaian proyek, pelaksanaan penilaian portofolio, serta pelaksanaan penilaian tes tulis pada yang dilakukan oleh guru SDN Model Banyuwangi. Dengan kata lain penelitian ini dapat menjadi acuan terhadap pengembangan pola asesmen berkelanjutan dalam merdeka belajar.

\section{B. Metode}

Pelaksanaan penelitian ini menggunakan pendekatan kualitatif deskriptif. Tahapan dalam penelitian ini terdiri dari tahap orientasi pra lapangan dan tahap kegiatan lapangan. Kegiatan yang dilakukan dalam tahap orientasi pra lapangan adalah yang pertama menyusun konsep dan menentukan fokus penelitian kemudian dilanjutkan dengan menyusun pedoman wawancara. Sedangkan untuk kegiatan yang dilakukan pada tahap kegiatan lapangan adalah peneliti melakukan penelitian ke lapangan dengan melakukan wawancara terhadap informan yang telah dipih yaitu guru koordinator kelas 1 sampai dengan kelas 5 (Sukmadinata, 2013).

Penelitian berlangsung di kabupaten Banyuwangi, Jawa Timur, tepatnya di SDN Model Banyuwangi yang beralamatkan di jalan Ikan Wijinongko 18, kelurahan Sobo, kecamatan Banyuwangi (68418). Kedudukan peneliti dalam penelitian adalah sebagai instrumen, pengumpul, penganalisis, penafsir data, dan akhirnya sebagai pelapor dari hasil penelitian. Oleh karena itu dalam penelitian kualitatif, instrumennya yaitu orang atau juga disebut sebagai human intstrument. Peneliti berperan untuk melakukan wawancara terhadap sumber yang bersangkutan untuk mengumpulkan data sebanyak mungkin.

Data yang diperoleh dalam penelitian ini berupa kalimat jawaban dari hasil wawancara serta didukung dengan dokumentasi kegiatan penelitian. Peneliti memilih kepala sekolah dan beberapa guru SDN Model Banyuwangi sebagai sumber wawancara. Untuk guru, peneliti melakukan wawancara kepada 5 guru, yaitu guru kelas 1, 2, 3, 4, dan 5. Diyakini bahwa keenam narasumber tersebut mengetahui secara langsung permasalahan yang sedang diteliti.

Analisis data yang digunakan oleh peneliti menggunakan teknik analisis data deskriptif kualitatif. Peneliti tidak melakukan kontrol dan manipulasi terhadap data yang di dapat. Peneliti hanya dapat merekam apa yang terdapat dalam wilayah penelitian dan kemudian memaparkan dalam bentuk laporan secara lugas. 
Uji keabsahan data dalam penelitian ini menggunakan uji kredibilitas data triangulasi dan menggunakan bahan referensi. Pada teknik Triangulasi peneliti membandingkan hasil wawancara yang dilakukan dengan guru sehingga diperoleh data yang sebanding atau yang akurat. Sedangkan pengujian kredibilitas yang selanjutnya adalah menggunakan bahan referensi yaitu peneliti merekam kegiatan yang berlangsung dengan menggunakan foto sebagai pendukung melakukan penelitian untuk menunjang dan pendukung data hasil wawancara.

\section{Pembahasan}

Hasil temuan penelitian yang dipaparkan dalam penelitian ini yaitu mengenai tanggapan guru terhadap penilaian autentik, pelaksanaan penilaian kinerja, pelaksanaan penilaian proyek, pelaksanaan penilaian portofolio, serta pelaksanaan penilaian tes tulis di SDN Model Banyuwangi.

Pertama, hasil penelitian menunjukkan bahwa terdapat berbagai macam tanggapan yang disampaikan oleh guru mengenai penilaian autentik dalam Kurikulum 2013. Terdapat beberapa kesulitan yang dialami oleh guru SDN Model Banyuwangi dalam mengimplementasikan penilaian autentik terhadap siswa. Kesulitan tersebut diantaranya yaitu masih banyak wali murid yang sulit untuk memahami maksud dari isi laporan hasil belajar putra-putri mereka yang berbentuk deskriptif. Selanjutnya, banyaknya indikator yang harus di nilai secara deskriptif, menyebabkan proses penilaian membutuhkan waktu yang cukup lama. Namun hal tersebut dirasa cukup adil bagi guru, karena nilai dalam bentuk angka saja dianggap sebagai penilaian secara sepihak pada aspek kognitif saja, sedangkan dalam penilaian autentik guru menganggap proses belajar yang telah dilakukan oleh siswa dapat lebih dihargai.

Kedua, pelaksanaan penilaian kinerja di SDN Model Banyuwangi dilaksanakan sebaik mungkin oleh guru. Setiap pelajaran akan dimulai, para guru di SDN Model Banyuwangi selalu menjelaskan indikator pembelajaran yang harus dicapai oleh seluruh siswa. Indikator yang dijelaskan seperti aspek kognitif, afektif, dan psikomotorik. Selain itu, tiap guru juga telah memiliki instrumen penilaian yang beragam seperti daftar cek, jurnal, serta lembar catatan anekdot yang telah dipersiapkan dari rumah sebelum pelajaran di mulai. Hal tersebut bertujuan untuk mempermudah proses penilaian yang akan dilakukan oleh guru terhadap siswa.

Dalam melakukan penilaian kinerja, self assessment merupakan rumpun penilaian yang tidak boleh terlewatkan. Self assessment atau lebih sering dikenal dengan penilaian diri menjadi sangat menarik ketika diterapkan di SDN Model Banyuwangi. Self assessment yang diterapkan di SDN Model Banyuwangi mendapat tanggapan yang positif dari siswa. Beberapa guru memiliki cara tersendiri ketika menyuruh siswa untuk 
menilai dirinya sendiri. Selain menilai dirinya sendiri, terkadang siswa diminta untuk menilai teman mereka. Hal tersebut dikenal dengan istilah penilaian teman sebaya.

Penilaian diri maupun penilaian teman sebaya dianggap memberikan banyak manfaat terhadap siswa. Salah satunya ialah menjadi umpan balik bagi siswa untuk mengintropeksi diri mereka secara keseluruhan. Namun meskipun demikian masih terdapat beberapa guru yang belum pernah menerapkan jenis penilaian ini.

Ketiga, penilaian proyek merupakan kegiatan penilaian terhadap tugas yang harus diselesaikan oleh peserta didik berdasarkan periode/waktu tertentu. Proses penilaian proyek dilakukan dengan cara yang berbeda oleh setiap guru. Di SDN Model Banyuwangi, tugas proyek yang diberikan kepada siswa tidak tergolong dalam kategori yang rumit. Guru selalu memberikan tugas yang sesuai dengan kemampuan siswa. Jangka waktu tugas proyek yang diberikan kepada siswa juga tidak terlalu lama, kurang lebih harus diselesaikan dalam waktu satu minggu.

Dalam memberikan tugas proyek, guru di SDN Model Banyuwangi lebih cenderung menyesuaikan dengan silabus dan RPP yang sudah ada. Namun para guru tidak mengadopsi begitu saja, melainkan mengembangkan dengan kreatifitas mereka masing-masing. Guru di SDN Model Banyuwangi merasa diberikan kemudahan dengan adanya silabus yang telah disusun oleh Kemendikbud. Selanjutnya, beberapa guru juga menyatakan bahwa hasil keterampilan siswa dari tugas proyek seringkali dipengaruhi oleh perhatian orangtua. Siswa yang memiliki orangtua yang peduli terhadap perkembangan belajar mereka cenderung memiliki karya yang lebih baik dibanding dengan mereka yang memiliki orangtua kurang peduli.

Keempat, Penilaian portofolio merupakan penilaian atas kumpulan artefak yang menunjukkan kemajuan dan dihargai sebagai hasil kerja dari dunia nyata. Di SDN Model Banyuwangi, guru memberikan tugas portofolio sesuai dengan pedoman yang telah ada di buku guru. Guru merujuk tugas portofolio pada silabus yang telah disusun oleh Kemendikbud, kemudian mengembangkannya sesuai dengan kreatifitas masingmasing. Penilaian portofolio pada siswa dianggap sebagai rekam jejak tugas yang pernah mereka kerjakan dalam periode tertentu. Guru di SDN Model Banyuwangi selalu menjelaskan tentang esensi dari tugas portofolio itu sendiri. Hal tersebut bertujuan agar siswa dapat memahami maksud dari diadakannya tugas portofolio.

Penyimpanan tugas portofolio sendiri dilakukan dengan cara yang sama. Tiap kelas atau ruang belajar di SDN Model Banyuwangi memiliki loker sejumlah siswa yang ada. Loker-loker tersebut telah diberikan identitas dari masing-masing siswa. Hal tersebut bertujuan agar siswa mendapatkan kemudahan dalam menyimpan tugas mereka. Masing-masing siswa memiliki file yang di kemas dalam map masing-masing. Tak jarang hasil karya siswa yang paling baik langsung dipamerkan di majalah dinding kelas. Hal tersebut berguna untuk memancing persaingan positif antar siswa dalam 
menghasilkan karya. Selain itu, guru juga sering memberikan apresiasi berupa hadiahhadiah kecil bagi siswa yang hasil karyanya dipamerkan di majalah dinding. Penilaian portofolio di SDN Model Banyuwangi memberikan pengaruh yang sangat besar terhadap perkembangan siswa. Siswa mendapatkan kemudahan ketika mereka ingin mempelajari kembali tugas yang pernah mereka kerjakan.

Kelima, tes tulis yang diberikan guru kepada siswa menyesuaikan dengan tema dan sub tema yang dipelajari oleh siswa. Penyusunan soal ulangan harian siswa disesuaikan dengan kompetensi dasar yang ada di buku siswa. Hal tersebut bertujuan agar siswa bisa fokus dalam belajar. Selanjutnya, dalam tes tulis di pertengahan semester (UTS) dan di akhir semester (UKK) guru di SDN Model Banyuwangi kerap menagadakan pertemuan rutin dengan Kelompok Kerja Guru (KKG) di kecamatan Banyuwangi yang berjumlah 14 sekolah. Dalam pertemuan rutin tersebut, para guru saling bertukar pikiran dalam menyusun soal ulangan untuk siswa. Dari jenis soalnya sendiri, guru mengatur sebaik mungkin komposisi antara soal pilihan ganda, jawaban singkat, dan uraian. Guru di SDN Model Banyuwangi sendiri sebenarnya lebih suka dengan model soal uraian. Hal tersebut dikarenakan jawaban siswa menunjukkan perkembangan kognitif siswa itu sendiri. Namun para guru juga menyadari bahwa tidak mungkin jika soal ulangan dibuat dalam bentuk uraian semua.

Berdasarkan hasil penelitian, dapat dinyatakan bahwa guru di SDN Model Banyuwangi telah menggunakan penilaian autentik sebagai penilaian pembelajaran. Hasil penelitian tersebut sesuai dengan Salinan Lampiran Permendikbud Nomor 104 tahun 2014 tentang Penilaian Hasil Belajar oleh Pendidik pada Pendidikan Dasar dan Pendidikan Menengah yang menyatakan bahwa Kurikulum 2013 mempersyaratkan penggunaan penilaian autentik (authenthic assessment).

Berdasarkan hasil penelitian selanjutnya, juga ditemukan bahwa pengertian penilaian autentik menurut salah seorang guru yaitu penilaian yang menyeluruh baik dari aspek sikap yang terdiri dari sikap sosial dan sikap religius, aspek pengetahuan, maupun aspek keterampilan yang dilakukan secara kontinyu atau berkelanjutan. Pengertian penilaian autentik menurut guru tersebut sesuai dengan pendapat Kunandar yang berpendapat bahwa penilaian autentik merupakan kegiatan menilai siswa yang menekankan pada apa yang seharusnya dinilai secara nyata, baik proses maupun hasil dengan berbagai instrumen penilaian yang disesuaikan dengan tuntutan kompetensi yang ada (Kunandar, 2014).

Dalam melakukan penilaian terhadap peserta didik, para guru memiliki instrumen tersendiri. Instrumen penilaian tersebut telah dikembangkan bersamaan dengan penyusunan RPP. Istrumen yang sering digunakan oleh guru dalam melakukan penilaian yakni jurnal, daftar cek (check list), dan catatan anekdot. Hal tersebut sesuai dengan pendapat Majid dan Ngadip yang menjelaskan bahwa terdapat beberapa cara 
berbeda untuk merekam hasil penilaian berbasis kinerja, dimana diantaranya adalah daftar cek (check list), catatan anekdot, skala penilaian, dan memori atau ingatan (Majid, 2014) (Ngadip, 2014).

Selanjutnya yakni penilaian proyek (project assessment). Penilaian proyek merupakan kegiatan penilaian terhadap tugas yang harus diselesaikan oleh peserta didik menurut periode/waktu tertentu. Penyelesaian tugas dimaksud berupa investigasi yang dilakukan oleh peserta didik, mulai dari perencanaan, pengumpulan data, pengorganisasian, pengolahan, analisis, dan penyajian data. Dengan demikian, penilaian proyek bersentuhan dengan aspek pemahaman, mengaplikasikan, penyelidikan, dan lain-lain (Majid, 2014).

Berkaitan dengan waktu yang diberikan pada siswa, para guru tidak pernah memberikan tugas yang rumit, sehingga waktu yang diberikan kepada siswa paling lama hanya berkisar satu minggu. Dengan tugas proyek ini diharapkan siswa dapat menghasilkan sebuah produk yang memiliki nilai esensi. Namun dalam melakukan penilaian, para guru tetap memperhatikan beberapa aspek.

Setidaknya ada tiga hal yang memerlukan perhatian khusus dari guru yakni keterampilan peserta didik dalam memilih topik, kesesuaian atau relevansi materi pembelajaran dengan pengembangan sikap, keterampilan, dan pengetahuan yang dibutuhkan oleh peserta didik, serta orisinalitas atas keaslian sebuah proyek pembelajaran yang dikerjakan atau dihasilkan oleh peserta didik (Mayasari, 2014). Namun, guru di SDN Model Banyuwangi memberikan pertimbangan tambahan untuk melakukan penilaian proyek terhadap siswa. Para guru selalu mempertimbangkan produk hasil karya siswa dengan kategori fast learner dan slow learner.

Dalam hal penilaian portofolio, Secara umum guru melaksanakan teknik penilaian portofolio melalui beberapa langkah, yaitu guru melaksanakan penilaian portofolio sesuai dengan kompetensi dasar, guru membuat kriteria penilaian portofolio yang disepakati bersama dengan siswa, siswa tidak hanya mencatat hasil penilaian portofolionya, tetapi siswa juga diajak untuk menilai hasil karyanya sendiri, guru mendokumentasikan hasil portofolio, guru memberikan umpan balik yaitu mengumumkan hasil yang paling bagus dengan tujuan memotivasi siswa yang memiliki hasil belum bagus supaya lebih meningkat dan memberikan kebanggaan bagi yang sudah bagus. Hasil portofolio siswa kemudian dirapikan dalam satu map, dimana mapmap tersebut kemudian disimpan di dalam loker pribadi siswa yang disediakan sekolah.

Pelaksanaan penilaian tes tulis di SDN Model juga sering dilakukan oleh para guru. Dalam teknik tes tertulis ini, guru memberikan soal dalam bentuk tulisan, baik yang ada di dalam lembar soal maupun yang ditulis di papan tulis. Selain itu, cara siswa menjawab soal yaitu dengan menuliskannya di kertas folio atau kertas jawaban yang telah disiapkan oleh guru. Hal tersebut sesuai dengan pendapat Kunandar (2014) dan 
Putri (2015) yang menjelaskan bahwa tes tertulis merupakan tes dimana soal dan jawaban yang diberikan dalam bentuk tulisan (Putri, 2015).

Guru di SDN Model Banyuwangi memiliki cara tersendiri dalam menyusun soal untuk tes tertulis. Soal yang sering diberikan pada siswa dapat berupa soal pilihan ganda, jawaban singkat, mencocokkan, dan uraian. Hasil penelitian tersebut sesuai dengan Salinan lampiran Permendikbud Nomor 104 tahun 2014 tentang Penilaian Hasil Belajar oleh Pendidik pada Pendidikan Dasar dan Pendidikan Menengah yang Menjelaskan bahwa bentuk soal tertulis dapat berupa memilih jawaban yaitu pilihan ganda, dua pilihan (benar-salah, ya-tidak), menjodohkan, dan sebab-akibat atau berupa menyuplai jawaban yaitu isian atau melengkapi, jawaban singkat atau pendek, dan uraian. Permendikbud tersebut juga menjelaskan bahwa soal tes tertulis yang menjadi penilaian autentik adalah soal-soal yang menghendaki siswa merumuskan jawabannya sendiri, seperti soal-soal uraian.

\section{Simpulan}

Berdasarkan penelitian, dapat disepakati bahwa asesmen autentik merupakan alat yang dapat mengukur perkembangan siswa dalam aspek afektif, kognitif, maupun psikomotorik. Meskipun terdapat anggapan bahwa instrumen penilaian yang harus dikembangkan oleh guru cukup banyak, namun asesmen tersebut mampu memberikan keterangan yang cukup rinci terhadap hasil belajar siswa serta bersifat berkelanjutan. Dengan demikian, asesmen autentik yang pernah diterapkan pada kurikulum 2013 dapat diintegrasikan pula pada kurikulum baru yang bernama merdeka belajar.

\section{Daftar Rujukan}

Adit, A. (2019). Gebrakan Merdeka Belajar, Berikut 4 Penjelasan Mendikbud Nadiem. Khasanah, E. R. (2015). Pelaksanaan Penilaian Autentik pada Kurikulum 2013 di SD Kota Mojokerto. Universitas Negeri Malang.

Kunandar. (2014). Penilaian Autentik Penilaian Hasil Belajar Peserta Didik Berdasarkan Kurikulum 2013. Jakarta: PT. Grafindo Persada.

Kusmijati, N. (2014). Penerapan Penilaian Autentik Sebagai Upaya Memotivasi Belajar Peserta Didik. In Proceeding Seminar Nasional LPP. Purwokerto.

Majid, A. (2014). Pembelajaran Tematik Terpadu. Bandung: PT . Remaja Rosda Karya. Mayasari, R. (2014). Studi Tentang Kemampuan Guru Dalam Melaksanakan Penilaian Autentik Pada Kurikulum 2013. Jurnal Kultur Demokrasi, 2(2).

Mulyasa, E. (2015). Pengembangan Implementasi Kurikulum 2013. Bandung: PT Remaja Rosdakarya.

Ngadip. (2014). Konsep Dan Jenis Penilaian Autentik (Authentic Assesment. Jurnal Dinas Pendidikan Kota Surabaya (Online).

Putri, A. C. (2015). Pelaksanaan Penilaian Autentik Dalam Pembelajaran Tematik Pada Siswa Kelas IV A Sekolah Dasar Negeri 4 Wates Kecamatan Wates 
Wiku Aji, Sigit Priatmoko

Kabupaten Kulon Progo. Universitas Negeri Yogyakarta.

Sukmadinata, N. S. (2013). Metode Penelitian Pendidikan. Bandung: PT . Remaja Rosda Karya. 